\section{Characterization of the Bentazon Herbicide Tolerance Factor in 'Bohemian Chili' Pepper}

\author{
Richard L. Fery ${ }^{1}$ and Howard F. Harrison, Jr. ${ }^{2}$ \\ United States Vegetable Laboratory, Agricultural Research Service, United \\ States Department of Agriculture, 2875 Savannah Highway, Charleston, \\ SC 29414-5334
}

Additional index words. Capsicum annuum, herbicide resistance, vegetable breeding, genetics

\begin{abstract}
Greenhouse and field studies were conducted to determine the genetic relationship between bentazon tolerance exhibited by the pepper (Capsicum annuum $\mathrm{L}$.) cultivars Bohemian Chili and Santaka, and to evaluate the importance of cytoplasmic factors in expression of the tolerance in 'Bohemian Chili.' Greenhouse evaluation of parental and $F_{2}$ populations of the cross 'Santaka' $x$ 'Bohemian Chili' indicated that the major dominant gene conditioning bentazon tolerance in 'Bohemian Chili' is probably the Bzt gene that conditions bentazon tolerance in 'Santaka' or a gene closely linked to the Bzt locus. Field evaluation of $F_{1}$ and $F_{2}$ progeny populations of the cross 'Bohemian Chili' $x$ 'Sweet Banana' in both 'Bohemian Chili' and 'Sweet Banana' cytoplasms demonstrated that cytoplasmic factors do not affect the expression of the bentazon tolerance gene in 'Bohemian Chili.' We conclude that 'Santaka' and 'Bohemian Chili' are equally satisfactory sources of a bentazon tolerance gene for use in pepper breeding programs. Chemical name used: 3-(1-methylethyl)-(1H)-2,1,3-benzothiadiazin-4(3H)-one 2,2-dioxide (bentazon).
\end{abstract}

Methyl bromide is used extensively in the United States as a preplant soil fumigant for controlling root-knot nematodes (Meloidogyne sp.) and yellow nutsedge (Cyperus esculentus L.) in commercial pepper plantings. Because this fumigant will not be available to U.S. growers after 1 Jan. 2001 (Crop Protection Coalition, 1995), alternative control measures need to be developed for both pests. Finding an effective control method for yellow nutsedge is particularly critical because this weed is an alternate host for the nematode (Schroeder et al., 1993). Schroeder et al. (1993) concluded that crop rotation cannot be used to manage root-knot nematodes in intensively managed pepper production systems if yellow nutsedge is not controlled.

Bentazon is a selective, postemergence herbicide used to control yellow nutsedge and several broadleaf weeds in a number of agronomic crops. Although highly toxic to many pepper cultivars and not currently registered for general use on the crop, bentazon is considered by some researchers to be an excellent candidate for postemergence control of yellow nutsedge in pepper. Studies by Baltazar et al. (1984), Harrison and Fery (1989, 1991), Pornprom and JongYeong (1997), and Wolff

\footnotetext{
Received for publication 29 Apr. 1998. Accepted for publication 20 Sept. 1998. The authors wish to acknowledge the assistance of Agricultural Research Technicians F.P. Maguire and N.L. Kelly. The cost of publishing this paper was defrayed in part by the payment of page charges. Under postal regulations, this paper therefore must be hereby marked advertisement solely to indicate this fact.

${ }^{1}$ Research Geneticist.

${ }^{2}$ Research Agronomist.
}

et al. (1989) demonstrated that $C$. апnиum germplasm exhibits a wide range of response to bentazon, and that the most tolerant accessions tolerate very high rates. The availability of highly tolerant germplasm suggests that it is possible to use classical plant breeding methodology to develop bentazon-tolerant $C$. annuum cultivars. The incorporation of bentazon tolerance into commercial cultivars and the subsequent registration of the herbicide for use on pepper would provide U.S. growers with an effective means of controlling yellow nutsedge in established pepper plantings.

Studies by both Wolff et al. (1989) and Harrison and Fery (1991) suggest that the desired sources of tolerance for breeding bentazon-tolerant peppers are the $C$. annuum cultivars Bohemian Chili and Santaka. Although Wolff et al. (1989) characterized three C. annuum plant introductions that exhibited a level of tolerance similar to that exhibited by 'Bohemian Chili' and 'Santaka', they noted that the introductions were quite variable in growth habit. Harrison and Fery (1991) evaluated the entire U.S. Capsicum Plant Introduction Collection for reaction to bentazon, and concluded that none of the 2694 accessions (representing six Capsicum species) evaluated was more tolerant than 'Bohemian Chili' or 'Santaka'.

Fery and Harrison (1990) reported that a single dominant gene (designated $B z t$ ) controls bentazon tolerance in 'Santaka'. Although the results of a greenhouse test suggested cytoplasmic involvement in the expression of the Bzt $t$ gene, the results of a field test provided strong evidence that cytoplasm does not play a significant role (Fery and Harrison, 1990).
Wolff et al. (1992) concluded that the tolerance to bentazon exhibited by 'Bohemian Chili' is conditioned by a single dominant gene and several modifying genes, and also reported "temporary" maternal effects in some populations.

There is considerable interest in developing bentazon-tolerant, bell-type pepper cultivars. The initial decision to be made at the onset of such a breeding program is the selection of an appropriate bentazon-tolerant parent. This paper reports the results of studies conducted to 1) determine the genetic relationship between bentazon tolerances exhibited by 'Bohemian Chili' and 'Santaka'; and 2) evaluate the importance of cytoplasmic factors in the expression of the bentazon tolerance exhibited by 'Bohemian Chili' under field conditions.

\section{Materials and Methods}

The data reported here are from field and greenhouse studies conducted at the U.S. Vegetable Laboratory, Charleston, S.C. Seeds of the parental and $F_{2}$ generations of the cross 'Santaka' $x$ 'Bohemian Chili' and the parental, $F_{1}$, and $F_{2}$ generations of the cross 'Sweet Banana' $x$ 'Bohemian Chili' were produced in the greenhouse using standard crossing and selfing procedures. The $F_{1}$ and $F_{2}$ generations of the latter cross were generated in both 'Sweet Banana' and 'Bohemian Chili' cytoplasms (reciprocal crosses). The bentazontolerant 'Bohemian Chili' has a determinate growth habit and small, pungent fruit borne in an erect position. Except for larger fruit size, the 'Santaka' phenotype is quite similar to that of 'Bohemian Chili'. 'Santaka' is homozygous for the Bzt gene conditioning bentazon tolerance (Fery and Harrison, 1990). 'Sweet Banana' is a popular commercial cultivar that is highly susceptible to bentazon.

Greenhouse study. Seeds of 'Keystone Resistant Giant' and the parental and $\mathrm{F}_{2}$ populations of the 'Santaka' $x$ 'Bohemian Chili' cross were germinated in vermiculite, and newly emerged seedlings were transplanted into 400 -mL styrofoam pots containing a commercial sphagnum peat-vermiculite mix. 'Keystone Resistant Giant' was included as a control; it is an open-pollinated, bell-type pepper that is moderately susceptible to bentazon injury. A completely randomized experimental design was used. Each of the homogeneous populations (cultivars) contained 40 test plants and the $\mathrm{F}_{2}$ population contained 115 test plants.

Bentazon was applied $25 \mathrm{~d}$ after transplanting at a rate of $4.5 \mathrm{~kg} \cdot \mathrm{ha}^{-1}$ ( $4 \times$ recommended rate) with a laboratory sprayer calibrated to deliver a spray volume of $272 \mathrm{~L} \cdot \mathrm{ha}^{-1}$; a crop oil concentrate was included at $0.5 \%$ of the spray volume. At 1 and 2 weeks after treatment, each plant was visually rated for herbicide injury (injury rating) on a scale of 0 to $10(0=$ no injury, $3=$ moderate foliar chlorosis with small necrotic lesions, $7=$ severe necrosis, and $10=$ dead plant).

Field study. The parental, $\mathrm{F}_{1}$, and $\mathrm{F}_{2}$ populations of the 'Sweet Banana' $\mathrm{x}$ 'Bohemian Chili' cross were seeded in the greenhouse on 
Table 1. Distribution of reactions of plants from the parental and $F_{2}$ populations of the cross 'Santaka' $x$ 'Bohemian Chili' (greenhouse study) and the parental, $F_{1}$, and $F_{2}$ populations of the cross 'Sweet Banana' $x$ 'Bohemian Chili' (field study) to a $4.5-\mathrm{kg} \cdot h \mathrm{~h}^{-1}$ application of bentazon. The $\mathrm{F}_{1}$ and $\mathrm{F}_{2}$ populations of the 'Sweet Banana' $x$ 'Bohemian Chili' cross were evaluated in both 'Bohemian Chili' and 'Sweet Banana' cytoplasms.

\begin{tabular}{|c|c|c|c|c|c|c|c|c|c|c|c|c|c|}
\hline & \multicolumn{11}{|c|}{ Injury rating class ${ }^{\mathrm{z}}$} & \multirow{2}{*}{$\begin{array}{c}\text { Total } \\
\text { plants } \\
\text { (no.) }\end{array}$} & \multirow{2}{*}{$\begin{array}{c}\text { Avg } \\
\text { injury } \\
\text { rating } \\
\end{array}$} \\
\hline Test population & 0 & 1 & 2 & 3 & 4 & 5 & 6 & 7 & 8 & 9 & 10 & & \\
\hline \multicolumn{14}{|c|}{ Greenhouse study (no. plants) } \\
\hline Santaka (S) & & & 6 & 20 & 9 & 4 & 1 & & & & & 40 & $3.4 \pm 0.2$ \\
\hline $\mathrm{F}_{2}(\mathrm{~S} \times \mathrm{BC})^{\mathrm{x}}$ & & 2 & 18 & 68 & 20 & 5 & & & 1 & 1 & & 115 & $3.2 \pm 0.1$ \\
\hline Keystone Resistant Giant ${ }^{\mathrm{w}}$ & & & & 1 & 1 & 5 & 10 & 15 & 5 & 3 & & 40 & $6.6 \pm 0.2$ \\
\hline Sweet Banana (SB) & & & & & 1 & 1 & 10 & 31 & 34 & 3 & & 80 & $7.3 \pm 0.1$ \\
\hline $\mathrm{F}_{1}(\mathrm{BC} \times \mathrm{SB})^{\mathrm{x}}$ & & 5 & 32 & 24 & 11 & 7 & 1 & & & & & 80 & $2.8 \pm 0.1$ \\
\hline $\mathrm{F}_{1}(\mathrm{SB} \times \mathrm{BC})^{\mathrm{x}}$ & & 4 & 29 & 30 & 8 & 6 & 1 & 2 & & & & 80 & $2.9 \pm 0.1$ \\
\hline $\mathrm{F}_{2}(\mathrm{BC} \times \mathrm{SB})^{\mathrm{x}}$ & & 12 & 46 & 39 & 14 & 25 & 6 & 12 & 2 & 1 & & 157 & $3.5 \pm 0.1$ \\
\hline $\mathrm{F}_{2}(\mathrm{SB} \times \mathrm{BC})^{\mathrm{x}}$ & & 24 & 41 & 34 & 20 & 17 & 10 & 7 & 5 & & & 158 & $3.3 \pm 0.1$ \\
\hline
\end{tabular}

${ }^{2}$ Each plant rated on a scale of 0 to $10 ; 0=$ no obvious injury and $10=$ dead plant.

${ }^{y}$ Mean \pm SE.

${ }^{\mathrm{x}}$ Maternal plant listed first.

${ }^{\text {wS }}$ usceptible control (bell-type cultivar).

28 Mar. and the plants were transplanted to the field on 10 May. The $\mathrm{F}_{1}$ and $\mathrm{F}_{2}$ populations were evaluated in both 'Sweet Banana' and 'Bohemian Chili' cytoplasms. The experimental design was a randomized complete block with four replications, each containing 16 plots. Each replicate contained two plots of each of the parental populations, two plots of each $F_{1}$ population, and four plots of each $\mathrm{F}_{2}$ population. Each plot consisted of a single row of 10 plants spaced $76 \mathrm{~cm}$ apart on beds $1 \mathrm{~m}$ apart. Bentazon was applied with a tractor-mounted sprayer on 16 June at the rate of $4.5 \mathrm{~kg} \cdot \mathrm{ha}^{-1}$. The sprayer was calibrated to deliver a spray volume of $187 \mathrm{~L} \cdot \mathrm{ha}^{-1}$; a crop oil concentrate was included at $1.25 \%$ of the spray volume. Each plant was rated on 23 June using the herbicide injury scale (0-10) described above.

\section{Results and Discussion}

Greenhouse study. Because the responses of plants to bentazon (injury rating) at 1 and 2 weeks after treatment were quite similar, only the data for the first week are presented. Plants of both 'Santaka' and 'Bohemian Chili' exhibited low to moderate injury, and plants of the susceptible control 'Keystone Resistant Giant' exhibited relatively high injury (Table 1). 'Santaka' was more severely injured by the bentazon application than was 'Bohemian Chili'. The injury rating mean for the $\mathrm{F}_{2}$ population was between the 'Santaka' and 'Bohemian Chili' means.

Examination of distributions for the injury ratings of the parental and $\mathrm{F}_{2}$ populations indicates that the $\mathrm{F}_{2}$ population was largely bentazon tolerant. Note that two of the $115 \mathrm{~F}_{2}$ plants did exhibit severe injury, but a low frequency of plants exhibiting severe susceptibility to bentazon was not unexpected because both parental populations typically exhibit similar reactions. For example, Fery and
Harrison (1990) noted that poorly developed or weak 'Santaka' seedlings can be severely damaged, particularly under greenhouse conditions, by high dosages of bentazon and are therefore easily misclassified. The relative value of the $\mathrm{F}_{2}$ mean with respect to the parental means and the lack of clear segregation pattern in the $\mathrm{F}_{2}$ population are strong evidence that the major gene proposed by Wolff et al. (1992) to condition bentazon tolerance in 'Bohemian Chili' is probably the Bzt gene conditioning the tolerance in 'Santaka' or a gene closely linked to the Bzt locus.

Field study. The results of the field study demonstrated clearly that 'Bohemian Chili' has a broad tolerance to bentazon under field conditions (Table 1). Although the 'Bohemian Chili' plants did not suffer any serious injury as a result of the $4.5-\mathrm{kg} \cdot \mathrm{ha}^{-1}$ application, the susceptible 'Sweet Banana' plants did. Examination of both the means and distributions of the $F_{1}$ and $F_{2}$ populations in the 'Bohemian Chili' and 'Sweet Banana' cytoplasms demonstrates clearly that cytoplasmic factors do not play a significant role in the expression of the bentazon tolerance gene in 'Bohemian Chili' under field conditions. 'Bohemian Chili' cytoplasm was not needed for full expression of the 'Bohemian Chili' tolerance gene. These results are consistent with those of an earlier study with 'Santaka' showing that 'Santaka' cytoplasm plays no role in the expression of the $B z t$ gene under field conditions (Fery and Harrison, 1990).

\section{Conclusions}

The results of our studies suggest that the major gene identified by Wolff et al. (1992) to condition bentazon tolerance in 'Bohemian Chili' is either the dominant Bzt gene identified by Fery and Harrison (1990) to condition bentazon tolerance in 'Santaka' or a gene closely linked to the Bzt locus. Examination of the expression of the 'Bohemian Chili' gene under field conditions indicates that 'Bohemian Chili' cytoplasm is not needed for full expression of bentazon tolerance. We conclude that 'Santaka' and 'Bohemian Chili' are equally satisfactory sources of a bentazontolerance gene for use in pepper breeding programs.

\section{Literature Cited}

Baltazar, A.M., T.J. Monaco, and D.M. Peele. 1984. Bentazon selectivity in hot pepper (Capsicum chinense) and sweet pepper (Capsicum annиum). Weed Sci. 32:243-246.

Crop Protection Coalition. 1995. National agricultural research needs resulting from regulatory actions on methyl bromide. Crop Protection Coalition, Watsonville, Calif.

Fery, R.L. and H.F. Harrison, Jr. 1990. Inheritance and assessment of bentazon herbicide tolerance in 'Santaka' pepper. J. Amer. Soc. Hort. Sci. 115:854-857.

Harrison, H.F., Jr., and R.L. Fery. 1989. Assessment of bentazon tolerance in pepper (Capsicum sp.). Weed Tech. 3:307-312.

Harrison, H.F., Jr., and R.L. Fery. 1991. Bentazon response of the U.S. plant introduction collection of pepper (Capsicum sp.). Weed Tech. 5:351-354.

Pornprom, T. and P. JongYeong. 1997. Differential tolerance of pepper cultivars to bentazon. Korean J. Weed Sci. 17:400-406.

Schroeder, J., S.H. Thomas, and L. Murray. 1993. Yellow and purple nutsedge and chile peppers host southern root-knot nematode. Weed Sci. 41:150-156.

Wolff, D.W., W.W. Collins, and T.J. Monaco. 1992. Inheritance of tolerance to the herbicide bentazon in peppers (Capsicum annuиm L.). J. Amer. Soc. Hort. Sci. 117:985-990.

Wolff, D.W., T.J. Monaco, and W.W.Collins. 1989. Differential tolerance of peppers (Capsicum апnиит) to bentazon. Weed Tech. 3:579583. 